\title{
Efektivitas Dana Desa Terhadap Pembangunan \\ Sumber Daya Manusia Pedesaan Melalui \\ Pendidikan Anak Usia Dini
}

\section{Nurtanggono Pamungkas}

Prodi Pendidikan Guru Pendidikan Anak Usia Dini, Fakultas Keguruan dan Ilmu Pendidikan, Universitas IVET, Indonesia

Info Articles

Sejarah Artikel:

Disubmit 2 Maret 2021

Direvisi 4 Maret 2021

Disetujui 3 Mei 2021

\section{Keywords:}

Effectiveness; Village Fund;

Early Education

\begin{abstract}
Abstrak
Desa memiliki peran strategis sebagai lokus pembangunan terkecil, atau dengan kata lain pembangunan nasional dimulai dari desa. Desa diindentikan sebagai ibu kandung suatu negara, yang berarti nuansa kehidupan masyarakat desa mencerminkan gambaran nyata kehidupan masyarakat pada suatu negara. Penelitian ini bertujuan untuk mendiskripsikan efektivitas Dana Desa terutama dalam bidang pembangunan sumber daya manusia pedesaan terutama bidang pendidikan melalui Program Pendidikan Anak Usia Dini sebagai salah satu aspek untuk mewujudkan pendidikan yang berkualitas dan berkelanjutan sebagaimana konsep SDGs Desa yang dicanangkan saat ini.
\end{abstract}

\section{Abstract}

Village has strategic roles as the smallest locus of development, or in other words the national development starts from a village. A village is identical with a birth mother of a country, in which the life nuance in the village society reflects a real description of social life of a country. The study aims to explore the effectiveness of the Village Fund in the human resource development more specifically in education area through the Program Early Education as an aspect to realize a quality and sustainable education in line with the concept of SDGs currently performed. 


\section{PENDAHULUAN}

Di dalam Undang-undang No 6 Tahun 2014 tentang Desa, dijelaskan bahwa desa merupakan kesatuan masyarakat hukum yang memiliki batas wilayah yang mempunyai wewenang untuk mengatur dan mengurus urusan penyelenggaraan pemerintah, pembangunan, dan kepentingan masyarakat setempat, mulai awal tahun 2015, desa mendapatkan sumber anggaran baru yakni dana desa yang bersumber dari anggaran pendapatandan belanja Negara ( APBN ) Setiap desa akan mengelola tambahan anggaran berupa dana desa yang akan di terima bertahap pembagian dana desa ini dihitung berdasarkan empat faktor yakni jumlah penduduk, luas wilayah, angka kemiskinan dan kualitas geografi (Alisjahbana, E.Murtubingtyas. 2018: 34).

Dana desa merupakan dana yang bersumber dari anggaran pendapatan dan belanja negara yang diperuntukkan bagi desa yang di transfer melalui anggaran pendapatan dan belanja daerah kabupaten/kota dan digunakan untuk membiayai penyelenggaraan pemerintahan, pelaksanaan pembangunan, pembinaan kemasyarakatan dan pemberdayaan masyarakat. Terutama melalui Peraturan Menteri Desa PDTT No. 13 Tahun 2020 yang mencakup tentang Prioritas Penggunaan Dana Desa diharapkan agar desa memiliki arah dan pandangan mengenai pemanfaatan Dana Desa, terutama eksistensi dan efektivitas dana desa berkaitan dengan pembangunan Sumber Daya Manusia (SDM) masyarakat pedesaan dalam mewujudkan pendidikan yang berkualitas dan berkelanjutan sebagaimana program Sustainable Development Goals (SDGs) Desa.

Menurut kamus besar bahasa Indonesia efektivitas merupakan efek, pengaruh, akibat atau dapat membawa hasil. Menurut Siagian (Siagian.2002: 20), efektivitas adalah daya guna, adanya kesesuaian dalam suatu kegiatan orang yang melaksanakan tugas dengan sasaran yang dituju. Selain itu, efektivitas merupakan hubungan antara output dengan tujuan, semakin besar kontribusi (sumbangan) output terhadap pencapaian tujuan, maka semakin efektif organisasi, program atau kegiatan. Adapun efektivitas menurut Mahmudi (2005:92) merupakan hubungan antara output dengan tujuan, semakin besar kontribusi (sumbangan) output terhadap pencapaian tujuan, maka semakin efektif organisasi program atau kegiatan. Berkaitan dengan pembangunan sumber daya manusia efektifitas dana desa diharapkan mampu mewujudkan desa sebagai pilot project pengembangan program pendidikan yang berkualitas bagi masyarakat pedesaan.

Secara umum pembangunan merupakan proses untuk melakukan perubahan menuju keadaan yang lebih baik. Untuk itu pembangunan harus dipahami dalam konteks yang luas karena terdapat kesepakatan yang mengatakan bahwa pembangunan harus mencakup segala segi kehidupan dan penghidupan bangsa dan negara yang bersangkutan meskipun dengan skala prioritas yang berbeda setiap daerah atau negara. Menurut Afifudin (Afifudin. 2012: 42), Pembangunan adalah pertumbuhan, yaitu kemampuan suatu negara untuk terus berkembang baik secara kuantitatif maupun kualitatif.

Undang-Undang Nomor 06 Tahun 2014 tentan Desa, dalam bab IX pembangunan desa dan pembangunan kawasan perdesaaan dijelaskan bahwa pembangunan desa adalah upaya peningkatkan kualitas hidup dan kehidupan untuk sebesar-besarnya kesejahteraan masyarakat desa. Lebih lanjut dijelaskan bahwa pembangunan desa bertujuan untuk meningkatkan kesejahteraan masyarakat desa dan kualitas hidup manusia serta penanggulangan kemiskinan melalui pemenuhan kebutuhan dasar, pembangunan sarana dan prasarana desa, pengembangan potensi ekonomi lokal, serta pemanfaatan sumber daya alam dan lingkungan secara berkelanjutan. 
Dengan demikian, pembangunan yang baik adalah pembangunan yang dilakukan secara berkelanjutan. Artinya melanjutkan apa yang telah dibangun, membangun yang belum dibangun dan menambah bagian-bagian baru sesuai kebutuhan nyata masyarakat. Prinsip pembangunan seperti ini yang perlu dilaksanakan dalam sebuah kepemimpinan di di desa. Hal ini dimaksudkan untuk menjaga kesinambungan hasil-hasil pembangunan yang telah dicapai dalam aktivitas pemerintahan dan pembangunan pada periode lima tahun sebelumnya, maka untuk memelihara serta melanjutkan aktivitas pemerintahan dan pembangunan dimaksud demi mencapai masyarakat desa yang maju, mandiri, damai dan sejahtera, perlu ditetapkan visi - misi pembangunan yang hendak dilaksanakan Visi-Misi yang ditetapkan hendaknya jelas sasaran yang hendak dibangun, sasaran yang dibangun itu dikehendaki menjadi apa setelah lima tahun baik dari sisi politik, ekonomi, sosial, dan budaya berazaskan nilai-nilai Pancasila .

Perlu kita pahami, bahwa pendidikan adalah usaha sadar dan terencana untuk mewujudkan suasana belajar dan proses pembelajaran agar peserta didik secara aktif mengembangkan potensi dirinya untuk memiliki kekuatan spiritual keagamaan, pengendalian diri, kepribadian, kecerdasan, akhlak, mulia, serta keterampilan yang diperlukan dirinya, masyarakat, bangsa dan negara (Pasal 1 angka 1, UU No 20 Tahun 2003 tentang Sisdiknas). Dari pengertian tersebut, bahwa setiap manusia memiliki kesempatan yang sama dalam hal memperoleh pendidikan yang layak. Sebagaimana dalam Undang-Undang Nomor 23 tahun 2002 pada Pasal 4 menyatakan, "Setiap anak berhak untuk dapat hidup, tumbuh, berkembang dan berpartisipasi secara wajar sesuai dengan harkat dan martabat emanusiaan serta mendapat perlindungan dari kekerasan dan diskriminasi"

Pendidikan Anak Usia Dini (PAUD) merupakan fase golden age atau masa peka. Golden age merupakan waktu paling tepat untuk memberikan bekal yang kuat kepada anak. Golden Age merupakan masa yang sangat tepat untuk menggali segala potensi kecerdasan anak sebanyakbanyaknya. Menurut NAEYC (National Association for The Education of Young Children), yang mengatakan bahwa anak usia dini merupakan anak yang berada pada rentang usia 0-8 tahun, yang tercakup dalam program pendidikan di taman penitipan anak, penitipan anak pada pada keluarga (family child care home), pendidikan prasekolah baik swasta maupun negri, TK, dan SD (Aisyah. 2007: 98).

Sebagai salah satu upaya pembinaan yang ditujukan kepada anak sejak lahir sampai dengan usia enam tahun yang dilakukan melalui pemberian rangsangan pendidikan untuk membantu pertumbuhan dan perkembangan jasmani dan rohani agar anak memiliki kesiapan dalam memasuki pendidikan lebih lanjut (Pasal 1 angka 14 UU No 20 Tahun 2003 tentang Sisdiknas). Program Pendidikan Anak Usia Dini (PAUD) di Pedesaan masih harus terus digalakan, karena dari indikator Angka Partisipasi Kasar (APK) program Pendidikan Anak Usia Dini ditingkat pedesaan masih rendah.

Oleh karena itu, dalam rangka meningkatkan target PAUD dan pelayanan masyarakat di bidang pendidikan tingkat pedesaan, maka perlu adanya suatu kebijakan penyerahan beberapa kewenangan dalam mendorong PAUD menjadi kewenangan lokal berskala desa. Yang mana menurut UU No 6 Tahun 2014 tentang Desa, pada Pasal 33 huruf b menyebutkan bahwa, kewenangan lokal berskala Desa, adalah kewenangan untuk mengatur dan mengurus kepentingan masyarakat desa yang telah dijalankan oleh desa atau mampu dan efektif dijalankan oleh desa atau yang muncul karena perkembangan desa dan prakasa masyarakat desa. Berdasarkan pertimbangan tersebut, beberapa kegiatan yang berkaitan dengan pengembangan PAUD dapat dianggarkan oleh 
Pemerintah Desa dalam Anggaran Pendapatan dan Belanja Desa terutama (APBDEs) melalui dana desa.

Dengan demikian dari latar belakang di atas, artikel ini akan mengulas mengenai tingkat Efektivitas Dana Desa Terhadap pembangunan Sumber Daya Manusia Pedesaan terutama melalui pendidikan. Selanjutnya akan dijelaskan mengenai implementasi dana desa dalam pengembangan program Pendidikan Anak Usia Dini (PAUD) di pedesaan sebagai salah satu aspek dalam mewujudkan pendidikan yang berkualitas dan berkelanjutan sebagaimana konsep SDGs Desa yang dicanangkan saat ini.

\section{METODE}

Penelitian ini menggunakan metode kualitatif deskriptif. Menurut Sugiyono, penelitian kualitatif adalah penelitian dimana peneliti ditempatkan sebagai instrument kunci, teknik pengumpulan data dilakukan secara penggabungan dan analisis data bersifat induktif (Sugiono.2010:9). Penelitian kualitatif menghasilkan dan mengolah data yang sifatnya desktiptif, seperti transkripsi, wawancara dan observasi (Purwandari.2005:10).

Dasar pemikiran yang digunakan dalam metode ini adalah karena penelitian ini ingin mengetahui fenomena yang ada dan dalam kondisi yang alamiah, bukan dalam kondisi terkendali, laboratoris, maupun eksperimen. Di samping itu, karena peneliti perlu langsung terjun ke lapangan bersama objek penelitian sehingga jenis penelitian kualitatif deskriptif kiranya lebih tepat digunakan.

Sesuai dengan permasalahan yang menjadi fokus dalam penelitian ini yaitu gambaran deskriptif mengenai efektivitas dana desa terhadap pembangunan sumber daya manusia pedesaan melalui program pendidikan anak usia dini (PAUD), maka peneliti menggunakan pendekatan kualitatif dengan mendeskripsikan data yang peneliti peroleh sebagai hasil penelitan. Dengan menggunakan metode ini, maka peneliti akan mendapatkan data secara utuh dan akan dideskripsikan dengan jelas sehingga hasil penelitian ini benar-benar sesuai dengan kondisi lapangan yang ada.

\section{HASIL DAN PEMBAHASAN}

\section{A. Hakikat Pendidikan Anak Usia Dini}

Manusia membutuhkan pendidikan dalam kehidupannya. Pendidikan merupakan usaha agar manusia dapat mengembangkan potensi dirinya melalui proses pembelajaran dan atau cara lain yang dikenal dan diakui oleh masyarakat, terutama pendidikan anak usia dini atau masa prasekolah dimana fase tersebut sangat penting dalam menentukan perkembangan anak selanjutnya. Pendidikan milik semua bangsa, milik semua masyarakat tanpa memandang strata sosial, ekonomi, agama, budaya dan ras. Pendidikan berhak dimiliki setiap individu. Pemerataan pendidikan di pelosokpelosok desa memberikan peranan bagi pendidikan anak pedesaan, terutama anak usia dini.

Menurut Pidarta (2007: 10), Pendidikan anak usia dini (PAUD) sangat strategis dalam pengembangan sumber daya manusia suatu bangsa. Tak hanya untuk menyiapkan tumbuh kembang anak menjadi sehat dan pintar, tapi juga berkarakter. Sebagaimana pendapat Langelveleld, bahwa pendidikan adalah memberi pertolongan secara sadar dan sengaja kepada anak (yang belum dewasa) 
dalam pertumbuhannya menuju kearah kedewasaan dalam arti dapat berdiri sendiri dan bertanggung jawab sesuai atas segala tindakannya menurut pilihannya sendiri. Selanjutnya menurut Bloom dan Sliznick menjelaskan bahwa fungsi pendidikan meliputi: Transmisi kebudayaan, Integrasi sosial, Inovasi dan Mengembangkan kepribadian anak (Ahmadi. 2007: 182).

Pengalaman dan pendidikan bagi anak merupakan faktor yang paling menentukan dalam perkembangan anak, yang mana PAUD dimaksudkan untuk memfasilitasi pertumbuhan dan perkembangan jasmani dan rohani anak usia dini agar dapat tumbuh dan berkembang secara optimal sesuai dengan nilai, norma dan harapan masyarakat.

\section{B. Efektivitas Dana Desa Dalam Pembangunan Sumber Daya Manusia}

Desa memiliki peran strategis sebagai lokus pembangunan terkecil, atau dengan kata lain pembangunan nasional dimulai dari desa. Desa diidentikan sebagai ibu kandung suatu negara, yang berarti nuansa kehidupan masyarakat desa mencerminkan gambaran nyata kehidupan masyarakat dalam suatu negara. Pencerminann sebagai negara yang berasaskan gotong royong dalam Pancasila meurpakan cerminan perilaku dan juga modal sosial dari masyarakat (Hermawan: 2015)

Pembangunan berupaya meningkatkan pendapatan bagi penduduk miskin desa, menjamin akses warga desa terhadap pelayanan sosial dasar, serta melindungi seluruh warga desa dari segala bentuk bencana. Untuk mencapai tujuan peningkatan pendapatan bagi penduduk miskin desa, maka target utama dari tujuan ini adalah peningkatan kualitas Sumber Daya Manusia (SDM) desa. Menurut Halim Iskandar (Halim Iskandar. 2020: 116), Pendidikan merupakan bentuk investasi yang menentukan masa depan bangsa. Pendidikan menjadi syarat peningkatan kualitas dan daya saing sumber daya manusia (SDM) desa. Oleh karenanya, untuk mencapai tujuan pembangunan yang berkelanjutan mengenai pendidikan yang berkualitas, maka yang harus dilakukan oleh pemerintah desa dengan dukungan dari supra desa adalah akses warga desa dalam memastikan ketersediaan layanan pendidikan yang berkualitas daan terjangkau bagi warga desa.

Disahkannya Peraturan Menteri Desa, Pembangunan Daerah Tertinggal dan Transmigrasi Nomor 11 Tahun 2019 tentang Prioritas Penggunaan Dana Desa tahun 2020 tentu membawa "angin segar" bagi semua lembaga pemerhati anak, khusus AUD. Hal ini Karena dalam Permendesa tersebut bukan saja program PAUD yang menjadi skala perioritas, namum juga konsep pengembangan anak usia dini holistik integratif (PAUD HI) memiliki ruang strategis sebagai prioritas.

Pasal 11 ayat 2 huruf a, Permendes PDTT Nomor 11 Tahun 2019 jelas mengatur prioritas penggunaan dana desa tahun 2020 mengenai peningkatan pelayanan publik bidang pendidikan dan kebudayaan di desa sebagaimana dimaksud dalam Pasal 6 ayat (4), paling sedikit meliputi :

a. Penyelenggaraan pendidikan anak usia dini (PAUD);

b. Penanganan anak usia sekolah yang tidak sekolah, putus sekolah karena ketidakmampuan ekonomi; dan

c. Pengembangan kebudayaan Desa sesuai dengan kearifan lokal.

Dalam lampiran 1 (BAB I poin e tentang Daftar Kegiatan Prioritas Bidang Pembangunan Desa) Permendesa nomor 11 tahun 2019 lebih rinci dijelaskan apa saja yang berkaitan dengan Anak Usia Dini yang menjadi prioritas dalam penganggaran dan perencanaan desa yaitu :

a. Taman bacaan masyarakat;

b. Bangunan PAUD bagi Desa yang belum ada gedung PAUD; 
c. Pengembangan bangunan/rehabilitasi gedung PAUD untuk PAUD HI;

d. Buku dan peralatan belajar PAUD lainnya;

e. Wahana permainan anak di PAUD;

f. taman belajar keagamaan;

g. Sarana dan prasarana bermain dan kreatifitas anak; 8) Pembangunan atau renovasi sarana olahraga Desa;

h. Bangunan perpustakaan Desa;

i. Buku/bahan bacaan;

j. Balai pelatihan/kegiatan belajar masyarakat;

k. Gedung sanggar seni/ruang ekonomi kreatif;

l. Film dokumenter;

m. Peralatan kesenian dan kebudayaan

n. Pembuatan galeri atau museum Desa;

o. Pengadaan media komunikasi, informasi, dan edukasi (KIE) terkait hak anak, gizi dan kesehatan ibu dan anak serta isu anak lain, keluarga berencana dan kesehatan reproduksi di Desa;

p. Sarana prasarana perjalanan anak ke dan dari sekolah yang aman bagi anak; da

q. Sarana prasarana pendidikan dan kebudayaan lainnya yang sesuai dengan kewenangan Desa dan diputuskan dalam musyawarah Desa.

Dukungan anggaran desa untuk, tentu akan berdampak pada kualitas Pendidikan Anak Usia Dini (PAUD), demi mewujudkan kualitas sumber daya manusia yang memadai. Peningkatan anggaran untuk PAUD sangatlah penting (Wahyudi, 2015). Hal ini dikarenakan bahwa Pendidikan Anak Usia Dini (PAUD) merupakan pendidikan yang sangat mendasar dan strategis untuk pembangunan Sumber Daya Manusia (SDM). Anton Jawamara menjelaskan bahwa, Pendidikan Anak Usia Dini (PAUD) adalah jenjang pendidikan sebelum jenjang pendidikan dasar yang merupakan suatu upaya pembinaan yang ditujukan bagi anak sejak lahir sampai dengan usia enam tahun yang dilakukan melalui pemberian rangsangan pendidikan untuk membantu pertumbuhan dan perkembangan jasmani dan rohani agar anak memiliki kesiapan dalam memasuki pendidikan lebih lanjut, yang diselenggarakan pada jalur formal, nonformal, dan informal (Anton Jawamara. 2021)

Pada usia dini 0-6 tahun, otak berkembang sangat cepat hingga 80 persen. Pada usia tersebut otak menerima dan menyerap berbagai macam informasi, tidak melihat baik dan buruk. Itulah masamasa yang dimana perkembangan fisik, mental maupun spiritual anak akan mulai terbentuk. Karena itu, banyak yang menyebut masa tersebut sebagai masa-masa emas anak (golden age). Pendidikan anak usia dini akan memberikan persiapan anak menghadapi masa-masa ke depannya, yang paling dekat adalah menghadapi masa sekolah (Agustiningrum, 2019).

Pemerintah desa memiliki landasan yuridis yang kuat untuk membuat perencanaan dan penganggaran desa untuk mendukung Program Pendidikan Anak Usia Dini (PAUD). Diharapkan pada tahun 2021 dan seterusnya ada peningkatan anggaran terkait hal tersebut, sebagaimana telah disahkan Permendes PDTT Nomor 13 Tahun 2020 tentang Prioritas Dana Desa Tahun 2021 yang berorientasi pada percepatan pencapaian tujuan pembangunan nasional yang berkelanjutan atau lebih dikenal dengan istilah Sustainable Development Goal (SDGs) Desa.

Undang-Undang Desa memandatkan bahwa tujuan pembangunan Desa adalah meningkatkan kesejahteraan masyarakat Desa dan kualitas hidup manusia serta penanggulangan kemiskinan melalui pemenuhan kebutuhan dasar, pembangunan sarana dan prasarana Desa, pengembangan potensi ekonomi lokal, serta pemanfaatan sumber daya alam dan lingkungan secara berkelanjutan. 
Yang dimaksud dengan berkelanjutan adalah pembangunan Desa untuk pemenuhan kebutuhan saat ini dilakukan tanpa mengorbankan pemenuhan kebutuhan generasi Desa di masa depan. Untuk mengoperasionalkan tujuan pembangunan Desa yang dimandatkan oleh Undang-Undang Desa, maka penggunaan Dana Desa diprioritaskan untuk mewujudkan 8 (delapan) tipologi Desa dan 18 (delapan belas) tujuan SDGs Desa yang salah satunya yakni Desa Peduli Pendidikan dengan tujuan mewujudkan pendidikan yang berkualitas.

Kajian yang dilakukan 33 Perguruan Tinggi yang tergabung dalam Forum Perguruan Tinggi untuk Desa (Pertides) pada tahun 2019, menunjukan manfaat yang dihasilkan dari dana desa di 33 Provinsi yakni (Halim Iskandar. 2020: 43) :

1. Pembangunan sarana dan prasaranan desa yang berdampak pada, Kelancaran kegiatan sosial yakni kegiatan tradisi masyarakat, taman baca, kepemudaan, Pendidikan Anak Usia Dini;

2. Akses masyarakat semakin mudah dan lancar menuju sekolah, baik PAUD, SD, SMP, SMA, maupun Kejar Paket.

Perlu dipahami bahwa banyak sekali kebutuhan dasar yang diprioritaskan dalam pengembangan Program Pendidikan Anak Usia Dini (PAUD) menuju pendidikan yang berkualitas, yakni:

1. Sarana dan Prasarana PAUD, meliputi:
a. Gedung PAUD;
b. Alat Permainan Edukatif (APE);
c. Taman Bacaan;
d. Alat tulis;

2. Peningkatan Kapasitas Sumber Daya Manusia
a. Insentif Guru PAUD;
b. Pelatihan dan Ketrampilan Guru PAUD;
c. Kesempatan pengembangan Pendidikan melalui beasiswa Desa;
d. Pemberian makanan yang bergizi untuk mencegah stunting.

Dikucurkanya Dana desa yang bersumber dari APBN oleh negara dengan jumlah yang sangat besar yakni 72 triliun pada tahun 2021, diharapkan mampu memberikan manfaat dan fasilitas bagi pengembangan program Pendidikan Anak Usia Dini. Karena eksistensi dana desa tersebut terdapat perkembangan yang sangat signifikan terhadap pembangunan masyarakat desa khususnya terkait dengan Program Pendidikan Anak Usia Dini (PAUD) di pedesaan. Selain program pembangunan nasional yang berkelanjutan, pendidikan masuk dalam kewenangan lokal berskala desa. Oleh karena itu, sebagai kebutuhan dasar masyarakat perlu sekali konsistensi dan komitmen pemerintah desa dalam mewujudkan desa peduli pendidikan dengan mewujudkan pendidikan yang berkualitas sebagai percepatan pencapaian pembangunan yang berkelanjutan atau dengan istilah Sutainable Development Goal (SDGs) desa.

\section{SIMPULAN}

Berdasarkan pembahasan di atas mengenai efektivitas dana desa terhadap pembangunan sumber daya manusia dapat disimpulkan, bahwa eksistensi dana desa dalam pembangunan sumber daya manusia pedesaan sangat bermanfaat terutama dalam pengembangan program Pendidikan Anak Usia Dini (PAUD). Pendidikan yang merupakan salah satu program prioritas pemerintah saat ini, maka dana desa di dorong untuk mendukung penyelenggaraan Program Pendidikan Anak Usia Dini (PAUD) baik dari aspek sarana dan prasarana, peningkatan kualitas Guru PAUD maupun dalam kesehatan melalui pemberian gizi pada peserta didik sebagai sarana pencegahan stunting. 
Dengan demikian, agar efektivitas penggunaan dana desa dalam melaksanakan pengembangan program Pendidikan Anak Usia Dini (PAUD), seyogyanya perlu adanya suatu pematangan program yang ada supaya dapat terukur melalui perencanaan berupa daftar rencana kerja agar ketika menemui suatu permasalahan dapat segera diketahui sumber masalah sehingga mempermudah dalam melakukan evaluasi untuk mencari solusi yang tepat.

\section{DAFTAR PUSTAKA}

Agustiningrum, M. D. B. (2019, January). Penggunaan Metode Audio-Lingual Dalam Proses Belajar Mendalang Sebagai Pemenuhan Fungsi Bahasa Anak Usia 5-10 Tahun (Studi Kasus Dalang Cilik). In Seminar Nasional Menduniakan Bahasa dan Sastra Indonesia.Afifudin. 2012. Pengantar Administrasi Pembagunan. Bandung: Alpabeta.

Ahmadi. (2007). Sosiologi Pendidikan. Jakarta: Rineka Cipta.

Aisyah. S. (2007). Perkembangan dan Konsep Dasar Pengembangan Anak Usia Dini. Jakarta: Universitas Terbuka

Alisjahbana, A.S,E Murniningtyas. (2018). Tujuan Pembangunan Berkelanjutan di Indonesia: Konsep Target dan Strategi Implementasi. Bandung: UNPAD Pr.

Halim Iskandar, A. (2020). SDGs Desa, Percepatan Pencapaian Tujuan Pembangunan Berkelanjutan, Jakarta: Yayasan Pustaka Obor Indonesia.

Hermawan, R. (2015). Desa Dalam Kerangka Negara Kesatuan Republik Indonesia: Melihat Desa Dari Sudut Pandang Aturan Perundang-undangan, Dalam Jurnal Desentraliasasi, Vol. 13, No.1.

Pidarta, M. (2007). Landasan Kependidikan. Jakarta: Rineka Cipta.

Siagian, (2002). Kiat Meningkatkan Produksi Kerja, Jakarta: Bhineka Cipta.

Undang-undang Nomor 6 Tahun 2014 tentang Desa

Permendes PDTT Nomor 11 Tahun 2019 tentang Prioritas Dana Desa Tahun 2020.

Permendes PDTT Nomor 13 Tahun 2020 tentang Prioritas Dana Desa Tahun 2021

Wahyudi, D., \& Arsana, I. M. (2014). Peran keluarga dalam membina sopan santun anak di desa galis kecamatan galis kabupaten pamekasan. Kajian Moral dan Kewarganegaraan, 1(2), 290-304. 